\title{
Analysis of Primary and Secondary Schools Information Literacy Research Situation in China
}

\author{
Jiasha Zhang, Jing Liu*, Min Hou, Jun Han \\ Department of Educational Technology \\ Capital Normal University \\ Beijing 100048, China
}

\begin{abstract}
Today, information literacy has become one of the essential qualities of every citizen. However, the college entrance examination system in China determines the information technology curriculum in primary and secondary schools in the lower position, which makes the information literacy training of students becoming a big problem. This paper first explains the Information Literacy training requirements of Information Technology Curriculum Guidelines for primary and secondary schools and obtaining the information literacy structure diagram of Primary and Secondary Schools information technology curriculum, and then, analyzes articles about information literacy training in CNKI with content analysis method, the results shows the short of the practice research about students' information literacy in Primary and Secondary schools and the information technology course is still not taken seriously in China.
\end{abstract}

Keywords-Information literacy; Information technology curriculum; primary and secondary schools

\section{INTRODUCTION}

Literacy is a certain accomplishment in theory, knowledge, art, ideas and other aspects. Information literacy is something related to information technology knowledge and ability and reflected personal ability and accomplishment in solving problems ${ }^{[1]}$, which is a measure of the overall quality of a person's indispensable part. The term Information literacy originally put forward by IIA Chairman Paul, which first appeared in the countries with a certain size information industry and also requires universal information literacy, such as the United States ${ }^{[2]}$.there is a lot of research on information literacy in China, but the trend is downward in recent years and the number of published articles is reduced. The paper will explain the Information literacy education of the Primary and Secondary Schools students by information technology curriculum criterion and use content analysis to analyze articles about primary and secondary school information literacy education in CNKI (National Knowledge Infrastructure) to deepen readers understanding. The purpose is to provide reference for the primary and secondary schools information technology courses and information literacy education of students. The author hopes that the information technology

It is sponsored by the key project of ministry of education for the planning of the national education science, "Learning assistant research based on affective computing ( DAC140239)” course in primary and secondary schools can be taken seriously through this article.

Content analysis is a specialized research method in educational technology and has clear, objective, systematic and quantitative characteristics ${ }^{[3]}$. Content analysis was first produced in the communication field, it is a kind of research method to study literature and describe the content, form and importance of a variety of materials and records objectively, systematically and quantitatively. The application modes of content analysis include feature analysis, development and comparative analysis. This paper uses the development analysis mode, also known as trend analysis. The process is usually first extracting representative data samples and decomposing samples into a series of analysis units, and then judging and recording them strictly according to prescribed categories of classification and dimensions system, the last one is counting and analyzing the results.

\section{INFORMATION LITERACY IN CURRICULUM STANDARDS}

December 2011, the Ministry of Education issued compulsory 19 subjects curriculum standards except for information technology. So far, the information technology curriculum standards in primary and secondary education is still the Guidelines for School information technology courses issued in2000 and Ordinary high school information technology curriculum standards in 2003. However, the new curriculum standards only emphasized that the information technology as an auxiliary tool for math learning to guide students effectively use calculators and computers in learning.

The Guidelines for School information technology courses stressed: through information technology courses enable students to have access to information getting, information transmission, processing information and application information and develop student's good information literacy ${ }^{[4]}$. That is to say, information technology subject is the main position of information literacy training and the core literacy of the course is information and technology literacy, the aim is to develop students' computer skills and capacity of obtaining, processing, management, expression, communication, evaluation and using of information, also to help students 
establishing a correct outlook on life and values. So, the information literacy structure diagram should be like Figure 1.

\section{STUDY OF PRIMARY AND SECONDARY SCHOOLS INFORMATION LITERACY AND PROBLEMS}

\section{A. Analysis of Primary and Secondary Schools Information Literacy}

The author search papers with the Professional method (SU=Information literacy AND SU=Primary and secondary schools) in CNKI, finding 527 effective articles from 2000 to 2015. The results are showing in Table 1 and the Figure 2. As it can be seen from Figure 2, since 2000, research on information literacy in primary and secondary schools is rising, but in recent years declined. The finds that only 87 papers on information literacy training of students, $17 \%$ of the total number of articles shown in Figure 3. However, research on teachers' information literacy accounted for $27 \%$, that is, researchers pay more attention to it and they believe that it is the premise of improving students' information literacy. The paper uses mainly analyzes with the method of content analysis from theoretical research and applied research. Theoretical study includes mainly the meaning of information literacy and the way, principles, patterns, and other forms of information literacy training. Applied research refers to exploring the training of information literacy using specific examples. The type of research is been classified as shown in Table 2 according to the results.

The theoretical research accounted for $72 \%$, the study found that most researchers mainly focus on the definition of information literacy from different perspective; they believe it is training students in information skills, information awareness and information ethical, information acquisition, processing and evaluation and using. Of course, researchers also study the modes, the principles and methods to train students' information literacy; they propose many views, such as effective curriculum integration and library education and so on.

By comparison, the practice research is relatively weak and only $28 \%$ shown in figure 4 , mainly conduct research on students' information literacy in a certain area, using a specific teaching case to do studies and also some teachers combine their experience to explore the education of information literacy, for instance, J. J. Zhang and others found that whether in the information knowledge aspects, or in information capacity and conditions, urban are showing greater dominance than rural primary school students and information technology courses in rural setting are needed to be strengthened ${ }^{[5]}$.

TABLE I. THE STATICS OF THE JOURNAL ARTICLES

\begin{tabular}{|c|c|c|c|}
\hline Years & Quantities & Years & Quantities \\
\hline 2000 & 2 & 2008 & 45 \\
\hline 2001 & 10 & 2009 & 52 \\
\hline 2002 & 18 & 2010 & 53 \\
\hline 2003 & 31 & 2011 & 41 \\
\hline 2004 & 16 & 2012 & 50 \\
\hline 2005 & 27 & 2013 & 46 \\
\hline 2006 & 29 & 2014 & 37 \\
\hline 2007 & 43 & 2015 & 27 \\
\hline Total & & 527 & \\
\hline
\end{tabular}

TABLE II. THE STATICS OF RESEARCH TYPES

\begin{tabular}{|c|c|c|c|c|c|}
\hline \multirow{2}{*}{ years } & \multicolumn{2}{|c|}{ research types } & \multirow{2}{*}{ years } & \multicolumn{2}{c|}{ research types } \\
\cline { 2 - 3 } & $\begin{array}{c}\text { theoretical } \\
\text { research }\end{array}$ & $\begin{array}{c}\text { applied } \\
\text { research }\end{array}$ & & $\begin{array}{c}\text { theoretical } \\
\text { research }\end{array}$ & $\begin{array}{c}\text { applied } \\
\text { research }\end{array}$ \\
\hline 2000 & 0 & 0 & 2009 & 8 & 2 \\
\hline 2001 & 3 & 0 & 2010 & 2 & 2 \\
\hline 2002 & 6 & 0 & 2011 & 4 & 2 \\
\hline 2003 & 5 & 4 & 2012 & 6 & 2 \\
\hline 2004 & 2 & 0 & 2013 & 4 & 4 \\
\hline 2005 & 2 & 0 & 2014 & 5 & 0 \\
\hline 2006 & 3 & 1 & 2015 & 4 & 1 \\
\hline 2007 & 5 & 2 & Total & 63 & 24 \\
\hline 2008 & 5 & 4 & & & \\
\hline
\end{tabular}

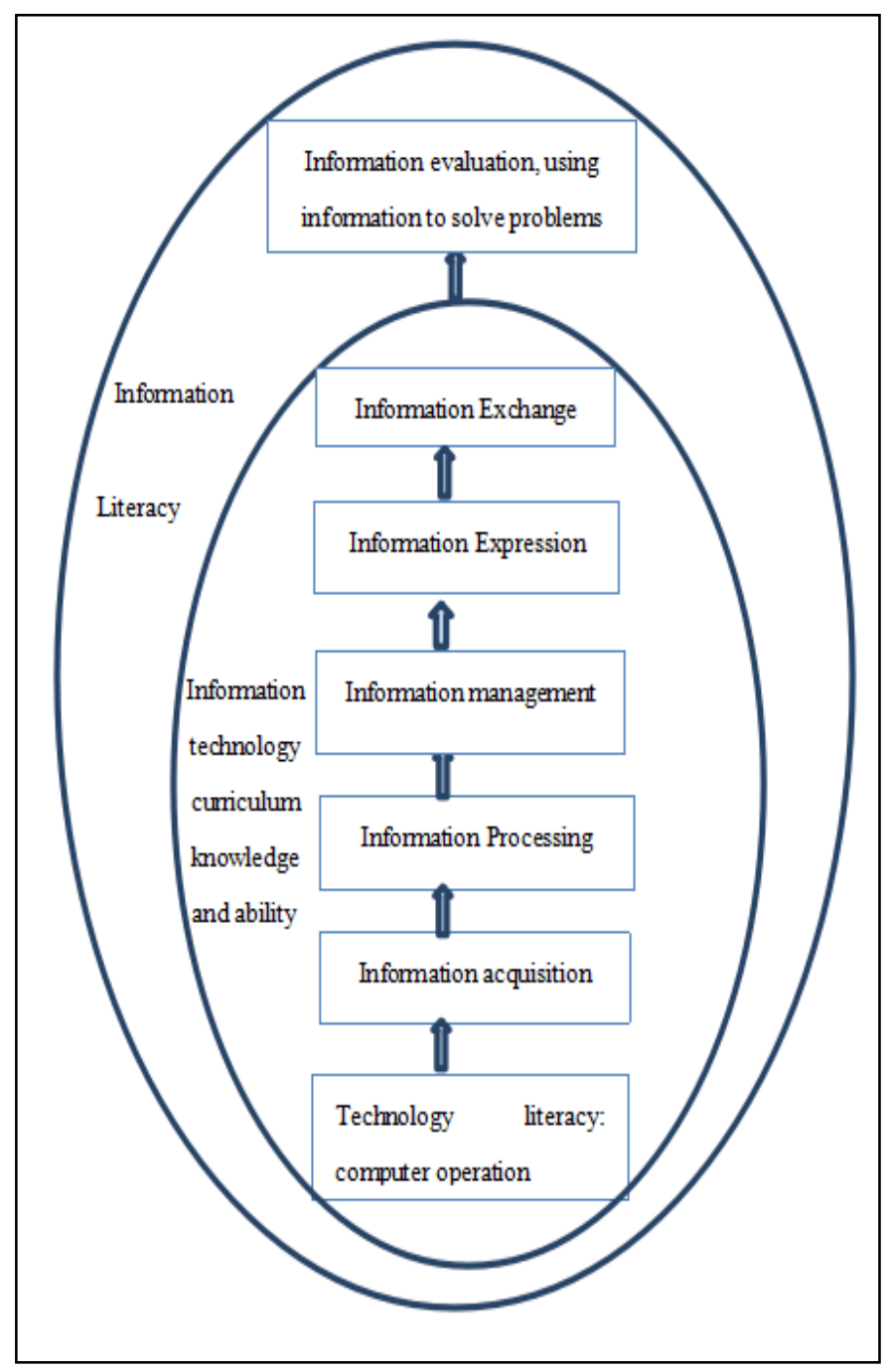

Figure 1. Information Literacy Structure Diagram

\section{B. Existing Problems and Suggestions}

1) Compared to Theoretical study, Applied Research is Weak: We can see from figure 3 that the applied research accounted for $28 \%$ and articles only 24 , articles of case studies are nine, practical investigation articles are eight and articles of proposing effective ways in the minority. So, in the future, researchers should put forward a specific practical way of 
training students' information literacy in combining theory and practice. What is more important, teachers should actively participate in the exploration of the team, provide a wealth of examples and suggestions for information literacy training. In addition, the researchers need to conduct research among the front-line teachers, provide more practical methods and models for the student's information literacy, rather than on paper.

2) Information Technology Courses Not Taken Seriously: Indeed, information technology curriculum did not get much attention from students, teachers and parents because the college entrance examination system, information technology itself lack of theoretical basis and not the main core subject. So, in order to take advantage of information technology courses to educate students' good information literacy, we must first pay attention to the subject. Information literacy is indispensable on evaluating one's overall quality in the information society, so we should set up such a view about information literacy, that is, quality education requires us to cultivate a comprehensive development and complete person, scores is certainly very important in today's Chinese society, but to improve the overall quality of students is more important, all the people not only schools should attach importance to the information literacy education.

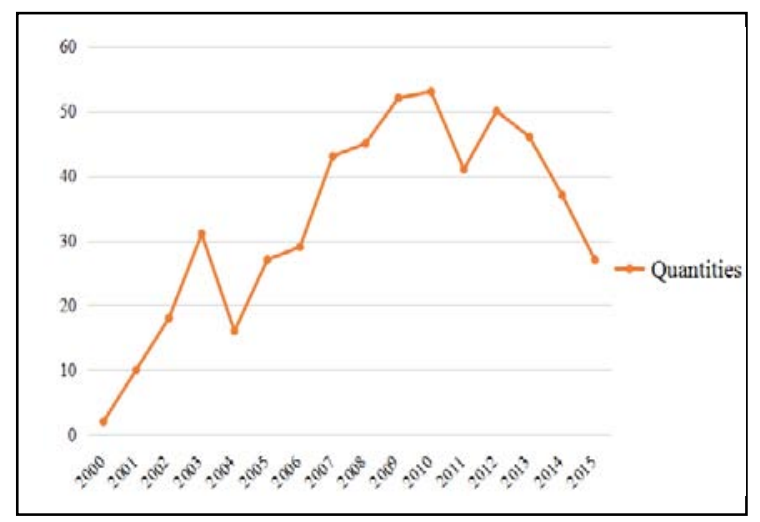

Figure 2. Information Literacy Articles Developing Trends

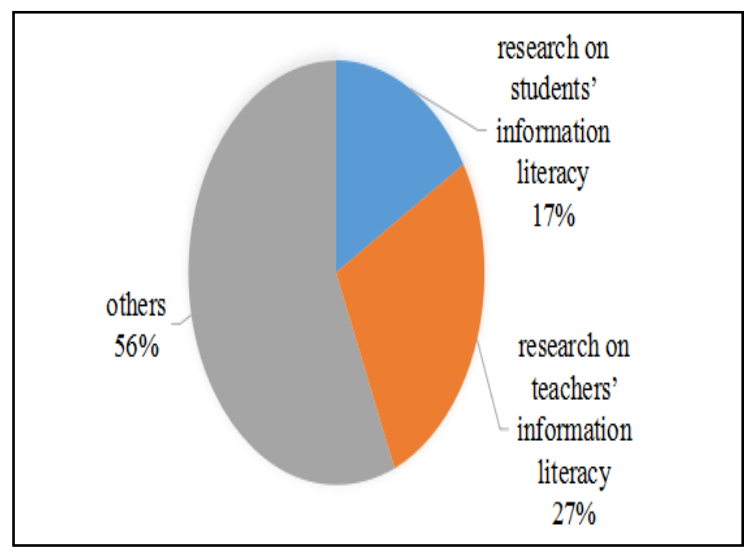

Figure 3. Research Types of research types

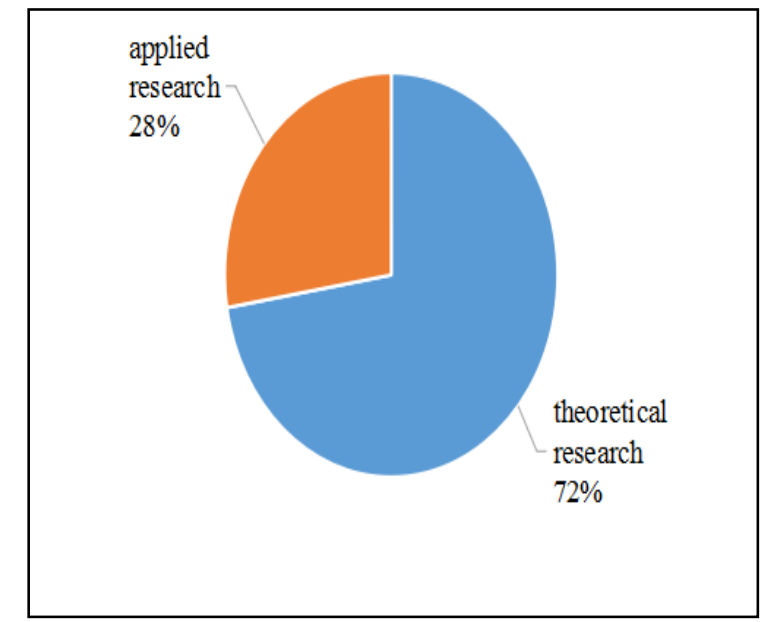

Figure 4. Proportion of the Theoretical Study and Applied Research

\section{ANALYZING OF THE RESULTS}

The information literacy development of student becomes the most concerned problem for the information technology course is not one of the main subjects. Researchers talk about how to develop information literacy and proposed a variety of methods, models, tools, ideas to try to make information technology courses been valued. The author believes that the following three aspects is the prerequisites and conditions of primary and secondary information literacy education:

\section{A. Improve Information Literacy of Teachers}

I believe that information literacy education cannot be formed and changed in a short time, so, the information literacy cultivating need to start from the basic education. The prerequisite for information literacy training are teachers own good professional skills and good information literacy. Teachers' Information Literacy determines the level of teaching quality, that is why many of researchers turned to teacher's information literacy study today and the research on teacher's information literacy accounted for $27 \%$ in figure 3 . Therefore, training and improving teachers' information literacy become a hot topic today and some scholars have put forward various suggestions for it.

\section{B. Fully Reflects the Classroom Life-Oriented}

The highest level of information literacy is the ability to use information, some researchers claimed that information technology curriculum should earnestly implement the education model of "teaching in life setting ", the learning content should be close to student life and teachers should reduce unnecessary knowledge teaching and students should combine learning and practicing effectively. Therefore, teachers should focus on students' information awareness training and teach students use the information skills to solve practical problems in life in order to strengthen their awareness of information, cultivating and improving their information literacy in this process. 


\section{Effective Curriculum Integration}

Since the academic background of information technology courses in primary and secondary schools is weak and academic status did not get much attention, so the integration of disciplines is the most respected way to raise Information literacy. I believe that curriculum integration is a way to make information technology courses valued, absolutely a way of information literacy training. If we could make information technology education penetrating to the main subjects such as Chinese, mathematics and servicing for other subjects as well as students can use the thinking of information acquisition, processing, and using to solve problems when learning other subjects, the information technology course will be integrated into other subjects.

\section{CONCLUSION}

The structure pattern is getting and the results of the study on articles in CNKI show that information technology course is the main subject to educate students' information literacy. But there are still a lack of practical research and information technology courses lack of attention. This paper mainly research on the topic of the information literacy education in primary and secondary schools in China with the content analysis method. Finally, I supposed that we should use the ways of improving teachers' information literacy, fully reflecting the classroom life-oriented when teaching and employing the effective curriculum integration to improve the students' information literacy. The research will go on to find more effective ways for the information technology curriculum and information literacy education, especially those in rural. Students' information literacy improving is the ultimate goal of the study.

\section{REFERENCES}

[1] X.N. Qiu. Focus on Cultivating the Students Information Literacy[J]. Heilongjiang Science and Technology Information. 2012

[2] G.Q. Jin. Information Literacy Education Overview in Information Society [J]. Library and Information Service.1995.

[3] J.P. Qiu, F.Zou. Research on Content Analysis, J. Chinese Library Journal. 2004

[4] Ministry of Education. Information Technology Curriculum Guidelines for Primary and Secondary Schools (Trial). The Ministry of Education Documents.

[5] J.J. Zhang, J.Cheng. Comparative Investigation of Chongqing Pupils' Information Literacy [J]. Shanghai Educational Research.2009.01. 